\title{
An interdisciplinary approach to assess the functional diversity of free-living microscopic eukaryotes
}

\author{
C. D. Lowe* , S. J. Kemp, D. J. S. Montagnes \\ School of Biological Sciences, University of Liverpool, Biosciences Building, Crown Street, Liverpool L69 7ZB, UK
}

\begin{abstract}
Free-living microbes are arguably ubiquitously dispersed. Molecular phylogeographies have been used to assess microbial distributions but can be difficult to interpret. Combinations of molecular and ecophysiological data have, however, proven useful in assessing the influence of dispersal, local adaptation and historical contingency on distributions. A logical extension of this approach is to develop molecular markers for ecophysiological traits, which would allow the assessment of adaptations in large numbers of environmental isolates without requiring extensive culturing. To assess this approach, we compared enzyme activity and gene expression of $\mathrm{Na}^{+} / \mathrm{K}^{+}$ATPase in response to salinity, and compared $\mathrm{Na}^{+} / \mathrm{K}^{+}$ATPase mRNA sequences, in 3 Brachionus plicatilis (Rotifera) sibling species. B. plicatilis siblings display different salinity tolerances, which in turn influence their distributions. $\mathrm{Na}^{+} / \mathrm{K}^{+}$ATPase is an important component of salinity tolerance and a potentially useful marker for ecophysiological variation. In all cases, $\mathrm{Na}^{+} / \mathrm{K}^{+}$ATPase enzyme activity and gene expression increased in response to salinity (5 to $50 \%$ ) and paralleled growth rate differences: highest enzyme activity/gene expression occurred in the sibling species that displayed highest growth. However, sequence variation in $\mathrm{Na}^{+} / \mathrm{K}^{+}$ATPase mRNAs was minor $(\sim 4 \%)$ and did not match gene expression patterns; thus, differences between siblings in $\mathrm{Na}^{+} / \mathrm{K}^{+}$ATPase occurred as a result of differential expression of highly similar gene transcripts. While we were not able to develop functional molecular markers for salinity tolerance in B. plicatilis, we highlight that the application of phylogenetic and functional markers will be a powerful tool for assessing the distributions of freeliving microorganisms.
\end{abstract}

KEY WORDS: Phylogeography $\cdot$ Salinity $\cdot$ Brachionus plicatilis $\cdot$ Osmoregulation $\cdot \mathrm{Na}^{+} / \mathrm{K}^{+} \mathrm{ATPase}$ Resale or republication not permitted without written consent of the publisher

\section{INTRODUCTION}

Macroscopic organisms tend to have limited spatial distributions as a result of constraints on their dispersal, their habitat requirements, and their historical contingencies (Fenchel 2003). It has been argued, however, that the distributions of organisms $<1 \mathrm{~mm}$ fundamentally differ from those of larger ones (e.g. Fenchel et al. 1997). The adage 'everything is everywhere - the environment selects' (Baas Becking 1934) suggests that microbes (prokaryotes, unicellular eukaryotes, and micrometazoans) achieve ubiquitous dispersal, facilitated by their small sizes and large populations. Thus, the distributions of free-living microbes are not constrained by historical contingency and lim- ited dispersal but by local habitat properties (Fenchel \& Finlay 2004).

There is some evidence from field observations and culturing experiments that free-living microbes are ubiquitous (Fenchel et al. 1997), but the argument remains contentious (e.g. Papke et al. 2003, Whitaker et al. 2003, Wilkinson 2003). In particular, the recent application of phylogeographic markers has provided cases that both support and challenge the notion of ubiquitous dispersal (e.g. Papke et al. 2003). Much of the contention over the ubiquity debate stems from difficulties in interpreting unusual genetic features (often inferred from single molecular markers) that are common for free-living microbes: examples of high genetic diversity on local scales (Moon-van der Staay et al. 
2001), large genetic distances between apparently closely related taxa (Rowan 1998, Saldarriaga et al. 2003), and phylogeographic discontinuities (Gomez et al. 2002) are common in the literature. It is now becoming clear that the application of a small number of phylogenetic markers is not sufficient to address these issues.

One of the more productive approaches to address these problems has been to assess phylogenetic diversity in context with functional differences, which reflect the ecology of the study organism. For example, ribosomal DNA (rDNA) genotypes of the marine cyanobacteria Prochlorococcus are widely geographically distributed but are associated with defined depths in oceanic water columns and display distinct depth-related responses to light; thus, in Prochlorococcus rDNA, diversity appears to represent locally adapted ecotypes maintained by habitat selection (Ferris \& Palenik 1998, Moore et al. 1998). In contrast, rDNA genotypes of cyanbacteria from isolated geothermal springs are confined to specific locales and show no correlation with potentially adaptive traits associated with habitat differences; hence, in this case rDNA diversity likely arose by geographic isolation (Papke et al. 2003). Studies such as these illustrate the value of combining phylogenetic and ecophysiological data to assess the factors influencing free-living microbial distributions.

There is, however, a further extension to the above approach. Adaptive traits (e.g. growth rate response of phytoplankton to light intensity) reflect complex phenotypes, potentially underpinned by numerous biochemical mechanisms. Understanding how traits evolve in response to habitat selection and the extent to which local adaptation influences dispersal and gene flow will depend on identifying the biochemical and, ultimately, the genetic basis of such traits. While the application of functional markers and the interpretation of variation in protein coding genes is appealing, and has certainly proved useful in the study of prokaryotic diversity (e.g. Palys et al. 1997), it must be carefully assessed.

In the present study, to illustrate an interdisciplinary approach, and potentially more rigorously assess diversity, we examine differences in a component of an adaptive trait (salinity tolerance) between sibling species of the rotifer Brachionus plicatilis. Sibling species in this complex are discrete (i.e. there is no gene flow) and display different physiological tolerances (Gomez et al. 2002, Ortells et al. 2003). As such, this is a useful species complex to study: using a comparative approach, we can examine highly similar organisms, with defined physiological tolerances, to assess differences in potential genetic components of these traits. Genetic components that are potentially useful as functional markers should parallel ecophysiological differences between sibling species.

Rotifers of the Brachionus plicatilis species complex are ubiquitous and common components of fresh and brackish water microbial ecosystems. Consequently, the ecology, physiology and phylogeny of these organisms are relatively well characterised (e.g. Walker 1981, Lubzens et al. 2001, Gomez et al. 2002). B. plicatilis sibling species occur in semi-permanent and ephemeral environments characterised by fluctuations in temperature, salinity, $\mathrm{pH}, \mathrm{O}_{2}$, and alkalinity (Derry et al. 2003b). Sibling species display differing adaptations to these environmental variables, which result in overlapping, but distinct, spatial and temporal distributions (Ortells et al. 2003).

It is well established that salinity, in particular, is a critical environmental factor affecting the growth (Miracle \& Serra 1989), the distributions (Gomez et al. 1995), and potentially the phylogenetic relationships between sibling species (Derry et al. 2003a). While a number of Brachionus plicatilis sibling species are known to be euryhaline, and their ecophysiological responses to salinity have been assessed (Gomez et al. 1997), our knowledge of the biochemical and molecular basis of salinity tolerance is limited in these organisms.

We have recently identified an osmoregulatory mechanism in Brachionus plicatilis as an important component of salinity tolerance (Lowe et al. 2005a): $\mathrm{Na}^{+} / \mathrm{K}^{+}$ATPase, a P-type ATPase ion transport protein, which is common to nearly all animal cells (Lingrel \& Kuntzweiler 1994). In addition, this enzyme is a well-characterised component of both hypo- and hyper-osmoregulation in many halophilic and euryhaline organisms (Holliday 1990, Lucu \& Devescovi 1999). In B. plicatilis, $\mathrm{Na}^{+} / \mathrm{K}^{+}$ATPase activity increases in response to salinity (indicative of hypo-osmoregulation) and accounts for up to $30 \%$ of total ATPase activity (Lowe et al. 2005a). Thus, differences in this mechanism between sibling species are likely to influence ecophysiological responses and distributions in the environment. We have, therefore, targeted this mechanism as a potentially useful tool for assessing adaptations to salinity. Specifically, we have examined $\mathrm{Na}^{+} / \mathrm{K}^{+}$ATPase in $3 \mathrm{~B}$. plicatilis sibling species. Using an interdisciplinary approach, we compared enzyme activity, sequences of the mRNAs coding for $\mathrm{Na}^{+} / \mathrm{K}^{+}$ATPase, and the relative expression of $\mathrm{Na}^{+} / \mathrm{K}^{+}$ATPase genes. We then interpret these differences in light of the ecophysiological responses of siblings and their phylogenetic relatedness (C. D. Lowe et al. unpubl.). Finally, we use this example to discuss the potential benefits and pitfalls of this interdisciplinary approach. 


\section{MATERIALS AND METHODS}

Maintenance of rotifer cultures. Three sibling species were analysed in this study. Brachionus plicatilis 6TUR and B. rotundiformis 6TOS, donated by $\mathrm{M}$. Serra, were isolates from Estany den Turies and Poza Sur in Spain, respectively (for details see Gomez et al. 2000). B. plicatilis IOM was provided by N. Fullerton (Larval Rearing Centre, Isle of Man). Previous phylogenetic analysis of mtcox1 sequences (C. D. Lowe et al. unpubl.) showed $B$. plicatilis 6 TUR to belong to the $B$. plicatilis 'ss' sibling species and $B$. plicatilis IOM to belong to the $B$. plicatilis 'Nevada' sibling species (terminology following Gomez et al. 2002). All rotifers were maintained on a diet of the flagellate Dunaliella salina as described by Lowe et al. (2005a).

$\mathrm{Na}^{+} / \mathrm{K}^{+}$ATPase activity in response to salinity. $\mathrm{Na}^{+} / \mathrm{K}^{+}$ATPase activity was examined as described by Lowe et al. (2005a). Briefly, $\mathrm{Na}^{+} / \mathrm{K}^{+}$ATPase activities (in rotifer isolates cultured at 7 salinities between 5 and $60 \%$ ) were examined as phosphate liberated from ATP by crude homogenates. For each treatment (isolate and salinity), 2 independent assays were conducted. For each assay, the density of the rotifer culture was estimated and a $200 \mathrm{ml}$ sample extracted. Samples were washed, first with sterile saline solution (corresponding to the salinity of the growth medium) and then with ice-cold homogenising medium $(0.25 \mathrm{M}$ sucrose, $6.0 \mathrm{mM}$ EDTA). Rotifers were concentrated, on a Nitex mesh filter (15 $\mu \mathrm{m}$ poresize), into $2.0 \mathrm{ml}$ of medium and processed on ice in ground glass homogenisers.

$\mathrm{Na}^{+} / \mathrm{K}^{+}$ATPase enzyme activity was determined as the difference between phosphate liberated in the presence of $\mathrm{K}^{+}$and in the absence of $\mathrm{K}^{+}$but with $1.0 \mathrm{mM}$ ouabain $\left(\mathrm{a} \mathrm{Na} / \mathrm{K}^{+}\right.$ATPase inhibitor; Lingrel \& Kuntzweiler 1994). Before the experiments, the assay was optimised for ouabain, ATP, and $\mathrm{K}^{+}$concentrations (Lowe et al. 2005a). For each assay, triplicates of 2 reactions were prepared, each $333 \mu \mathrm{l}$ in volume with $66.7 \mu \mathrm{l}$ of homogenate: a $\mathrm{K}^{+}$reaction containing (final

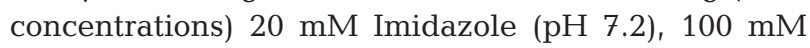
$\mathrm{NaCl}$, and $30 \mathrm{mM} \mathrm{KCl}_{\text {; a K}}-$ reaction containing (final concentrations) $20 \mathrm{mM}$ Imidazole (pH 7.2), $130 \mathrm{mM}$ $\mathrm{NaCl}$, and $1.0 \mathrm{mM}$ ouabain. Before starting assays, tubes were equilibrated to $30^{\circ} \mathrm{C}$ for 5 min. Blank (homogenising medium) and phosphate standards (0.60 $\mathrm{mM} \mathrm{Na}_{2} \mathrm{HPO}_{4}$ ) were prepared in duplicate and also incubated. Reactions were started by adding a solution containing $15 \mathrm{mM} \mathrm{Na}_{2}$ ATP and $30 \mathrm{mM} \mathrm{MgCl}_{2}$ and incubated for $15 \mathrm{~min}$. Reactions were stopped by adding $1.5 \mathrm{ml}$ Bonting's colour reagent $\left(\mathrm{H}_{2} \mathrm{SO}_{4}\right.$, ammonium molybdate, $\mathrm{FeSO}_{4}$ ) and were allowed to develop for $20 \mathrm{~min}$. Absorbance was measured at $700 \mathrm{~nm}$ (Ultrospec 2000, Pharmacia Biotech).
$\mathrm{Na}^{+} / \mathrm{K}^{+}$ATPase activity was calculated as phosphate released protein $\mathrm{mg}^{-1} \mathrm{~h}^{-1}$. Protein concentrations of homogenates were determined using the Bradford method (Bradford 1976, Sambrook \& Russell 2001). Differences between responses were analysed using ANCOVA (Zar 1999).

Total RNA extraction and cDNA synthesis. For RNA extractions, aliquots of $\sim 2000$ rotifers were harvested and washed with sterile saline solution. Rotifers, collected into $2 \mathrm{ml}$ cryotubes (Nalgene), were centrifuged to form a pellet, the saline solution was removed, and samples were stored under liquid nitrogen. For the initial RNA extractions, used to isolate potential $\mathrm{Na}^{+} / \mathrm{K}^{+}$ ATPase transcripts, rotifers were subjected to an additional wash step to ensure the removal of prey. After the initial wash, rotifers were left for $12 \mathrm{~h}$ in saline solution, to allow digestion of ingested food. Rotifers were then washed again in sterile saline and pelleted for storage.

RNA was extracted from rotifer tissue using Trizol, following the manufacturer's instructions (Invitrogen). Samples were removed from liquid nitrogen and homogenised in $1 \mathrm{ml}$ of Trizol in RNase-free glass homogenisers. To remove contaminating genomic DNA, samples were treated with DNase (DNA-free, Ambion). The effectiveness of the treatment was confirmed by polymerase chain reaction $(\mathrm{PCR})$ on a quantitative PCR thermocycler (Corbett Rotogene), using actin-specific primers (see ' $\mathrm{Na}^{+} / \mathrm{K}^{+}$ATPase gene expression and quantitative PCR' below) and DNasetreated RNA as template. Samples testing positive for genomic DNA were re-treated. The quality and concentration of RNA samples were determined using the RNA 6000 nano assay on the Agilent Biochip analyser (Agilent Technologies). RNA samples showing degradation were discarded. cDNA was synthesised using StrataScript reverse transcriptase, following the manufacturer's instructions (Stratagene). Reactions $(25 \mu \mathrm{l})$ consisted of $19 \mu \mathrm{l}$ RNA template (diluted to $\left.\sim 200 \mathrm{ng} \mathrm{\mu l}^{-1}\right), 1.5 \mu \mathrm{l}$ random primers $\left(100 \mathrm{ng}^{-1} \mathrm{l}^{-1}\right), 2.5 \mu \mathrm{l}$ $10 \times$ StrataScript buffer, $1 \mu \mathrm{l}$ dNTP $(100 \mathrm{mM})$, and $0.5 \mu \mathrm{l}$ StrataScript reverse transcriptase $\left(50 \mathrm{U} \mathrm{\mu l}^{-1}\right)$.

Isolation of $\mathrm{Na}^{+} / \mathrm{K}^{+}$ATPase transcripts. Potential $\mathrm{Na}^{+} / \mathrm{K}^{+}$ATPase transcripts were isolated using a (PCR) based strategy. Conserved regions of the $\mathrm{Na}^{+} / \mathrm{K}^{+}$ATPase $\alpha$-subunit were identified from published alignments of amino acid sequences for P-type ATPases. PCR primers were designed using the CODEHOP primer strategy (Rose et al. 1998). Primers (Table 1) were located within 3 conserved regions of the protein: domain B (SLTGESE, small loop), domain E (CSDKTGTLT, phosphorylation site), and domain G (TGDGVND, ATP binding site; terminology from Axelsen \& Palmgren 1998).

PCRs were performed using Hotstar taq DNA polymerase (Qiagen) and a touchdown cycle to increase 
Table 1. Degenerate and non-degenerate PCR primers used to amplify IIC P-type ATPases and reference genes actin and ubiquitin $\mathrm{C}$ in Brachionus plicatilis 6TUR, Brachionus plicatilis IOM and B. rotundiformis 6TOS. Primers for reference genes were designed from sequences available in GenBank (accession numbers given in parentheses)

\begin{tabular}{|lc|}
\hline & Product size (bp) \\
\hline Primer & \\
IIC P-type ATPases & \\
Sma1 F 5'-CTCCCTGACCGGCGARWSNGARCC-3' & \\
Phos1 F 5'-TCTGCTCCGATAAGACCGGNACNYTNAC-3' \\
ATP1 R 5'-GCGGGGGAATCGTTCCANCCRTCNCC-3' \\
Fragment A (putative Na'/K' ${ }^{+}$ATPase) & 1517 \\
F 5'-CAAAATCGCATGACTGTGG-3' & \\
R 5'-AATTTTTGTTGCGGAGAAG-3' & \\
Fragment B & \\
F 5'-TGCTCTGATAAGACTGGTAC-3' & \\
R 5'-GGTGACGGTGTTAACGA-3' & \\
F 5'-GCTCATATGTGGCTTGGAAATAA-3' & \\
R 5'-CGAGCATCTTAGTCCTCTGACAA-3' & \\
Quantitative PCR primers & \\
Fragment A & \\
F 5'-TGTGCCTGATGCTGTTGAGAAATG-3' & \\
R 5'-GAACAACAACAGCTTTGGCATCAC-3' & \\
Fragment B & \\
F 5'-GCCAGAGGCCATTTCCAGATGTA-3' & \\
R 5'-TCAATTGGGACCCATGAACAA-3' & \\
Reference gene & \\
Actin (AB111352) & \\
F 5'-AACAGCCGGCATCCACGAGACC-3' & \\
R 5'-TTGGCGCCAGGGCAGTGATTTC-3' & \\
Ubiquitin C (AB076054) & \\
F 5'-CAATCTGTTCGAGTGGGAGGTG-3' & \\
R 5'-TGGTGGCAAATCTGACTGACG-3' & \\
\end{tabular}

The identities of cDNAs were examined using the BLAST search suite of programs (Altschul et al. 1997). Both nucleotide and derived amino acid sequences were searched against the NCBI database. To confirm identities of putative IIC P-type ATPases isolated from Brachionus plicatilis siblings, derived amino acid sequences were included in a phylogenetic analysis of P-type ATPases. An alignment of the conserved domains of IIA-C, IIIA and IIIB P-type ATPase sequences from a broad taxonomic range of organisms (Table 2) was subject to neighbour-joining analysis (MEGA v3.0).

$\mathrm{Na}^{+} / \mathrm{K}^{+}$ATPase gene expression and quantitative PCR. The relative expression of the putative $\mathrm{Na}^{+} / \mathrm{K}^{+}$ATPase transcripts in Brachionus plicatilis siblings was examined in response to 7 salinities ( 5 to $60 \%$ ). Culturing and harvesting were performed as detailed above, except that the additional wash step (12 h incubation in sterile saline solution) was omitted. Rotifers remained alive and free-swimming until pelleted by centrifugation, at which point they were frozen in liquid nitrogen.

Gene expression was examined by quantitative RT-PCR on the Rotogene system (Corbett) using the Quantace SYBR green QPCR kit (Quantace) and following the method of (Pfaffl 2001). Before the experiments, the amplification efficiencies of primer pairs and the consistency of expression of the control genes were tested. Expression of the putative $\mathrm{Na}^{+} / \mathrm{K}^{+}$ATPase transcripts was normalised against 2 housekeeping genes (actin and ubiquitin $\mathrm{C}$ ) and presented relative to expression at $10 \%$. PCR conditions were optimised for temperature $\left(58\right.$ to $68^{\circ} \mathrm{C}$ ) and concentrations of $\mathrm{cDNA}, \mathrm{MgCl}_{2}$, and primers. PCRs were performed in $10 \mu \mathrm{l}$ volumes, following the manufacturer's instructions, and contained $20 \mathrm{pmol}$ primer (see Table 1) and 8 ng cDNA; cycling conditions were $95^{\circ} \mathrm{C}$ for $15 \mathrm{~min}, 40$ cycles at $95^{\circ} \mathrm{C}$ for $6 \mathrm{~s}, 68^{\circ} \mathrm{C}$ for $25 \mathrm{~s}$, and $72^{\circ} \mathrm{C}$ for $45 \mathrm{~s}$. At each salinity, relative expression was estimated from 3 independent samples of each rotifer isolate. For each treatment (isolate, salinity, replicate), 3 technical replicates were performed to check consistency.

\section{RESULTS}

\section{$\mathrm{Na}^{+} / \mathrm{K}^{+}$ATPase activity in response to salinity}

Kinetic responses of $\mathrm{Na}^{+} / \mathrm{K}^{+}$ATPase to substrate and inhibitor concentrations were previously characterised sequenced to confirm identities. 
Table 2. IIA-IIC, IIIA and IIIB P-type ATPases obtained from GenBank (accession numbers given) used in the phylogenetic analysis (see Fig. 3). Superscript letters identify known ion specificities: a, $\mathrm{Ca}^{2+} ; \mathrm{b}_{1} \mathrm{H}^{+} / \mathrm{K}^{+} ; \mathrm{c}, \mathrm{Na}^{+} / \mathrm{K}^{+} ; \mathrm{d}, \mathrm{H}^{+} ; \mathrm{e}, \mathrm{Mg}^{2+}$. Numbers (1-85) refer to terminal branches in Fig. 3

\begin{tabular}{|c|c|c|c|c|c|}
\hline No. & $\begin{array}{c}\text { GenBank } \\
\text { accession no. }\end{array}$ & Species & No. & $\begin{array}{c}\text { GenBank } \\
\text { accession no. }\end{array}$ & Species \\
\hline \multicolumn{3}{|c|}{ Type IIA } & \multicolumn{3}{|c|}{ Type IIC (continued) } \\
\hline 1 & P37278 & Synechococcus elongatus & 44 & Q92030 & Anguilla anguilla \\
\hline 2 & P37367 & Synechocystis sp. & 45 & P25489 & Catostomus commersoni \\
\hline 3 & M93017 & Rattus norvegicus & 46 & P50993 & H. sapiens ${ }^{\mathrm{b}}$ \\
\hline 4 & P13586 & Saccharomyces cerevisiae ${ }^{\mathrm{a}}$ & 47 & U15176 & $R$. norvegicus \\
\hline 5 & U65981 & Cryptosporidium parvum & 48 & P17326 & A. franciscana ${ }^{\mathrm{b}}$ \\
\hline 6 & U39298 & Plasmodium falciparum & 49 & P20648 & H. sapiens ${ }^{\mathrm{C}}$ \\
\hline 7 & U65066 & Trichomonas vaginalis & 50 & U17249 & Xenopus laevis ${ }^{\mathrm{c}}$ \\
\hline 8 & P54209 & Dunaliella bioculata & 51 & D21854 & Cavia cobaya \\
\hline 9 & U70540 & Leishmania amazonensis & 52 & P54707 & H. sapiens ${ }^{\mathrm{C}}$ \\
\hline 10 & P35315 & Trypanosoma brucei & 53 & P54708 & $R$. norvegicus ${ }^{\mathrm{c}}$ \\
\hline 11 & L40328 & Schistosoma mansoni & 54 & Z25809 & Bufo marinus ${ }^{\mathrm{c}}$ \\
\hline 12 & P16615 & Homo sapiens ${ }^{\mathrm{a}}$ & & & \\
\hline 13 & U65228 & Makaira nigricas & \multicolumn{3}{|c|}{ Type IIIA } \\
\hline 14 & X63009 & Rana esculenta ${ }^{\mathrm{a}}$ & 55 & U67563 & Methanococcus jannaschii \\
\hline 15 & M99223 & R. norvegicus ${ }^{\mathrm{a}}$ & 56 & P54210 & Dunaliella acidophila $^{\mathrm{d}}$ \\
\hline 16 & P18596 & R. norvegicus ${ }^{\mathrm{a}}$ & 57 & P54211 & D. bioculata \\
\hline 17 & $\mathrm{P} 22700$ & Drosophila melanogaster & 58 & P54679 & D. discoideum \\
\hline 18 & P35316 & Artemia franciscana & 59 & D88424 & Cyanidium caldarium \\
\hline 19 & Q08853 & P. falciparum & 60 & X76535 & Solanum tuberosum \\
\hline 20 & X55197 & Plasmodium yoelii & 61 & Q03194 & Nicotiana plumbaginifolia \\
\hline 21 & M96324 & Lycopersicon esculentum & 62 & P19456 & A. thaliana ${ }^{\mathrm{d}}$ \\
\hline 22 & U82966 & Oryza sativa & 63 & P20431 & A. thaliana ${ }^{\mathrm{d}}$ \\
\hline 23 & U93845 & Arabidopsis thaliana & 64 & S79323 & Vicia faba \\
\hline \multirow{2}{*}{\multicolumn{3}{|c|}{ Type IIB }} & 65 & X85805 & Zea mays \\
\hline & & & 66 & U84891 & Mesembryanth. cryatallinum \\
\hline 24 & U05880 & Paramecium tetraurelia & 67 & D31843 & O. sativa \\
\hline 25 & X99972 & Brassica oleracea $^{\mathrm{a}}$ & 68 & U09989 & Z. mays \\
\hline 26 & L08468 & A. thaliana & 69 & D10207 & O. sativa \\
\hline 27 & U20321 & Entamoeba histolytica & 70 & M27888 & N. plumbaginifolia ${ }^{\mathrm{d}}$ \\
\hline 28 & U15408 & $R$. norvegicus & 71 & X85804 & Phaseolus vulgaris \\
\hline 29 & P23634 & H. sapiens ${ }^{\mathrm{a}}$ & 72 & P24545 & Z. rouxii ${ }^{\mathrm{d}}$ \\
\hline 30 & P20020 & H. sapiens ${ }^{\mathrm{a}}$ & 73 & P28877 & Candida albicans \\
\hline 31 & Q16720 & H. sapiens ${ }^{\mathrm{a}}$ & 74 & P49380 & Kluyveromyces lactis \\
\hline 32 & Q01814 & H. sapiens ${ }^{\mathrm{a}}$ & 75 & P05030 & S. cerevisiae ${ }^{\mathrm{d}}$ \\
\hline 33 & P54678 & Dictyostelium discoideum & 76 & P19657 & S. cerevisiae d $^{\mathrm{d}}$ \\
\hline 34 & P38929 & S. cerevisiae $\mathrm{a}^{\mathrm{a}}$ & 77 & U65004 & Pneumocystis carinii \\
\hline \multicolumn{3}{|c|}{ Type IIC } & 78 & P28876 & Schizosaccharomyces pombe \\
\hline 35 & U70316 & D. discoideum & 79 & P09627 & S. pombe $\mathrm{d}^{\mathrm{d}}$ \\
\hline 36 & Z81457 & C. elegans & 80 & P07038 & Neurospora crassa ${ }^{\mathrm{d}}$ \\
\hline 37 & P35317 & Hydra vulgaris ${ }^{\mathrm{b}}$ & 81 & Q07421 & Histoplasma capsulatum \\
\hline 38 & P28774 & Artemia franciscana & 82 & P12522 & Leishmania donovani \\
\hline 39 & U18546 & Caenorhabditis elegans ${ }^{\mathrm{b}}$ & & & \\
\hline 40 & P13607 & D. melanogaster & \multicolumn{3}{|c|}{ Type IIIB } \\
\hline 41 & P05023 & H. sapiens ${ }^{b}$ & 83 & P22036 & Salmonella typhimurium ${ }^{\mathrm{e}}$ \\
\hline 42 & P05025 & Torpedo californica ${ }^{\mathrm{b}}$ & 84 & P39168 & Escherichia coli ${ }^{\mathrm{e}}$ \\
\hline 43 & P13637 & H. sapiens ${ }^{\mathrm{b}}$ & 85 & P36640 & S. typhimurium \\
\hline
\end{tabular}

(Lowe et al. 2005a). Under the culturing strategy used, protein content per rotifer was independent of both rotifer culture density ( 2 to 50 rotifers $\mathrm{ml}^{-1}$, slope not different from 0; Fig. 1a), and salinity (slope not different from 0 ; Fig. 1b) for the 3 rotifer isolates. For the enzyme assay, estimates of protein concentration were linear with the number of rotifers homogenised (Fig. 1c), and $\mathrm{Na}^{+} / \mathrm{K}^{+}$ATPase activity in homogenates was linear with homogenate protein concentration (Fig. 1d). Thus, there was no bias associated with nonlinear relationships between protein content of rotifers and culture density or salinity, or between protein concentration and enzyme activity.

$\mathrm{Na}^{+} / \mathrm{K}^{+}$ATPase activity increased in response to salinity for the 3 sibling species (Fig. 2a). The response to salinity was similar in all cases. ATPase activity 

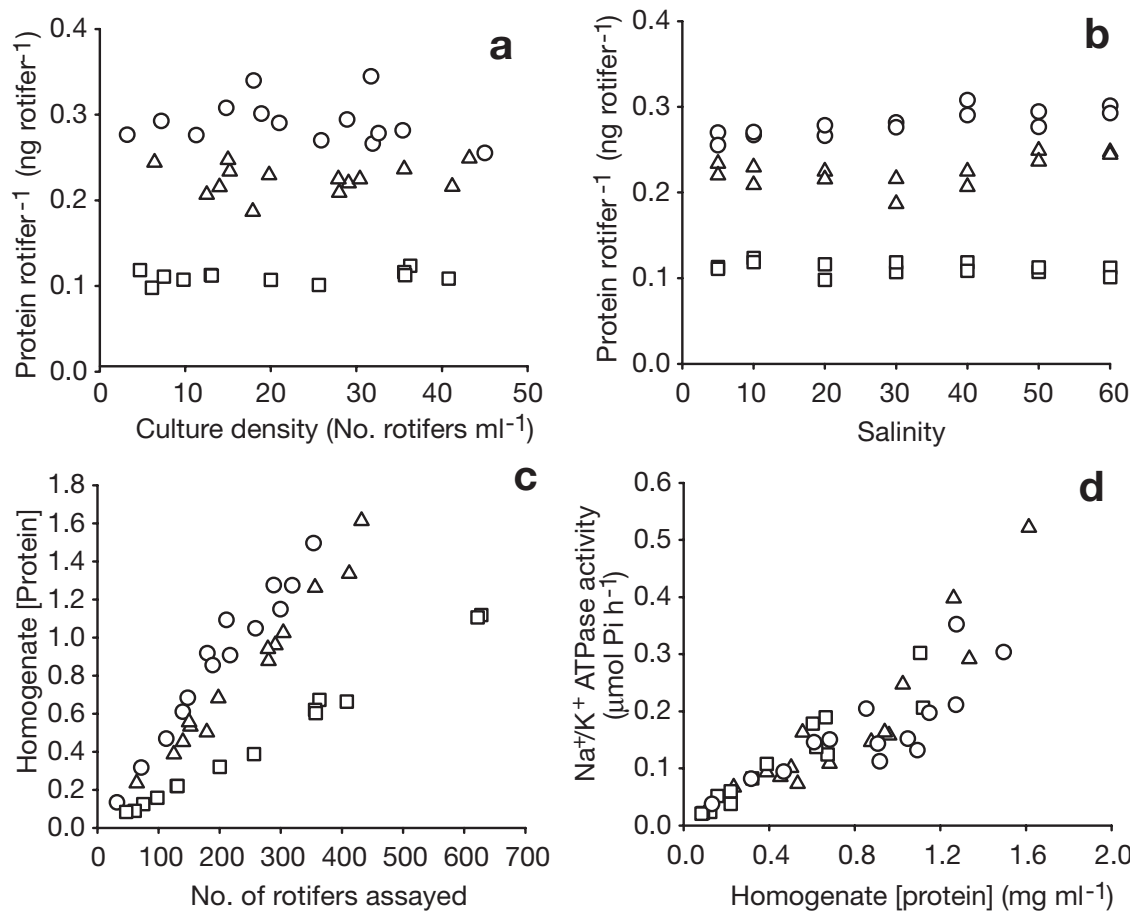

Fig. 1. Effect of (a) culture density and (b) salinity on the protein content of Brachionus plicatilis 6TUR $(O), B$. plicatilis IOM $(\Delta)$, and $B$. rotundiformis 6 TOS ( $\square$ ). Relationship between (c) protein concentrations of homogenates and the number of rotifers assayed and (d) $\mathrm{Na}^{+} / \mathrm{K}^{+}$ATPase activity and homogenate protein concentrations

increased linearly between 5 and $50 \%$, followed by a decrease at $60 \%$. Over the linear portion of the responses, differences were assessed using ANCOVA. The slopes of the responses were equal $\left(F_{2,30}=0.19\right.$, $\mathrm{p}=$ not significant [ns]); however, the elevation of the response for Brachionus rotundiformis 6TOS was significantly higher than for the B. plicatilis 6TUR and B. plicatilis IOM $\left(F_{2,32}=8.62, \mathrm{p}<0.05\right)$.

\section{Identification and comparison of $\mathrm{Na}^{+} / \mathrm{K}^{+}$ATPase transcripts}

Two different transcripts were isolated via PCR: fragment A ( 1.5 kb, spanning conserved domains B and G) and fragment $\mathrm{B}(\sim 1.1 \mathrm{~kb}$, spanning conserved domains $\mathrm{E}$ and G). Fragment A was identified in all 3 isolates. However, fragment B was identified only in Brachionus plicatilis 6TUR and B. plicatilis IOM; despite several rounds of screening we were unable to amplify fragment B from B. rotundiformis 6TOS.

cDNA fragment A was identical in Brachionus plicatilis 6TUR and B. rotundiformis 6TOS and shared $96.4 \%$ identity with $B$. plicatilis IOM. Fifty-five synonymous changes occurred and were concentrated between conserved domains $\mathrm{E}$ and $\mathrm{F}$ (terminology b following Axelsen \& Palmgren 1998). Five amino acid replacements occurred: 3 between domains $\mathrm{E}$ and $\mathrm{F}$ and 2 between domains $F$ and $G$. cDNA fragment B shared $98 \%$ identity between B. plicatilis 6TUR and B. plicatilis IOM. Twenty-two synonymous nucleotide substitutions occurred and were again concentrated between conserved domains $\mathrm{E}$ and $\mathrm{F}_{;} 2$ non-synonymous changes occurred (sequence alignments are available on request from the corresponding author).

Database searches suggested that both fragments coded for IIC ATPase $\alpha$ subunits $\left(\mathrm{Na}^{+} / \mathrm{K}^{+}\right.$or $\mathrm{H}^{+} / \mathrm{K}^{+}$ATPase). Nucleotide BLAST and protein BLAST searches (using amino acid sequences directly translated from the cDNA fragments) indicated high similarity of both fragments to $\mathrm{Na}^{+} / \mathrm{K}^{+}$and $\mathrm{H}^{+} / \mathrm{K}^{+}$ATPases in the platyhelminthes Schistosoma mansoni (Trematoda) and Dugesia japonica (Turbellaria), and the arthoropods Carcinus maenas (Crustacea) and Anopheles gambiae (Insecta). In addition, the E1-E2 ATPase protein motif, characteristic of P-type ATPases, was detected in fragment $\mathrm{A}$, and conserved protein domains characteristic of IIC P-type ATPase $\alpha$-subunits occurred in both fragments.

To determine which of the IIC P-type ATPases $\left(\mathrm{Na}^{+} / \mathrm{K}^{+}\right.$, or $\mathrm{H}^{+} / \mathrm{K}^{+}$ATPase) cDNA fragments A and B coded for, alignments of conserved regions of the amino acid sequences for type IIA-IIC, IIIA and IIIB ATPase $\alpha$-subunits from a range of organisms (Table 2) were subject to phylogenetic analysis (following Axelsen \& Palmgren 1998). Protein sub-families formed discrete clades (Fig. 3) and within the IIC subfamily $\mathrm{Na}^{+} / \mathrm{K}^{+}$and $\mathrm{H}^{+} / \mathrm{K}^{+}$ATPases formed sub-clades. Fragments $\mathrm{A}$ and $\mathrm{B}$ were highly diverged from each other. Fragment A grouped within the $\mathrm{Na}^{+} / \mathrm{K}^{+}$ATPase clade; thus we putatively identify this fragment as a $\mathrm{Na}^{+} / \mathrm{K}^{+}$ ATPase. The identity of fragment $B$, which occurred basally within the IIC clade along with sequences for Dictyostelium discoideum (GenBank accession number U70316) and Caenorhabditis elegans (GenBank accession number Z81457), was uncertain.

\section{Expression of putative $\mathrm{Na}^{+} / \mathrm{K}^{+}$ATPase transcripts}

In all cases, relative expression of $\mathrm{Na}^{+} / \mathrm{K}^{+}$ATPase, normalised to actin/ubiquitin $\mathrm{C}$, increased in response to salinity (Fig. 2b). Assuming responses were linear, 

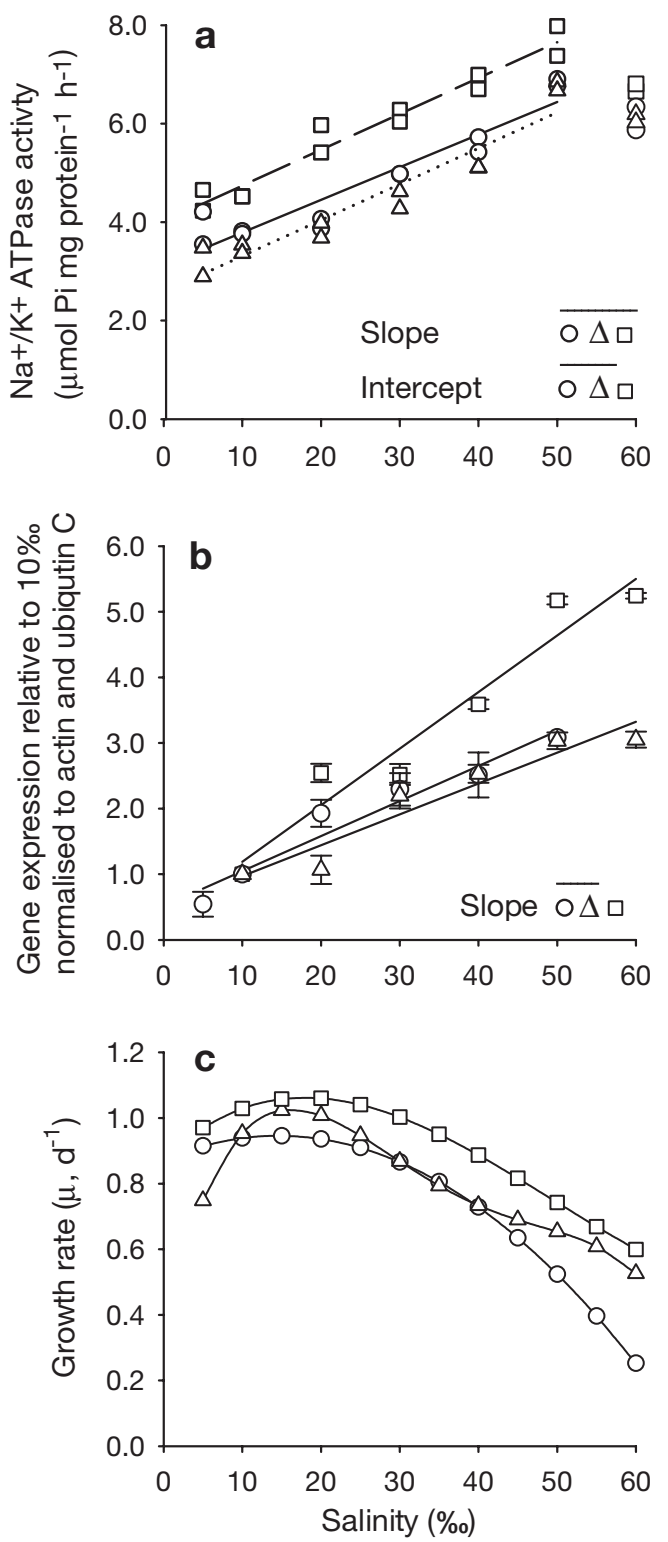

Fig. 2. (a) $\mathrm{Na}^{+} / \mathrm{K}^{+}$ATPase activity in Brachionus plicatilis 6TUR $(\mathrm{O})$, B. plicatilis IOM $(\Delta)$, and B. rotundiformis 6TOS ( $\square$ ) grown at 5 to $60 \%$ salinity (symbols represent the same sibling species in all panels). (b) Expression of putative $\mathrm{Na}^{+} / \mathrm{K}^{+}$ ATPase of sibling species in response to salinity; expression was normalised to actin and ubiquitin $\mathrm{C}$ and given relative to expression at $10 \%$. For (a) and (b), regression models fitted to the linear portion of the responses were compared using ANCOVA. Bars over symbols in the legends (for a and b) indicate that parameters (i.e. slope and intercept for a, slope for $b)$ were not significantly different $(p=0.05)$. (c) Modelled acclimated growth rate responses of $B$. plicatilis sibling species (adapted from C. D. Lowe et al. unpubl.)

the rate of increase in relative expression was significantly higher in Brachionus rotundiformis 6TOS than in B. plicatilis 6TUR and B. plicatilis $\operatorname{IOM}\left(F_{2,16}=48.45\right.$, $\mathrm{p}<0.05)$. The relative expression of $\mathrm{Na}^{+} / \mathrm{K}^{+}$ATPase, normalised to actin/ubiquitin $\mathrm{C}$, increased 5.5-fold between 10 and $50 \%$ for $B$. rotundiformis 6TOS. No differences in relative expression occurred between the $B$. plicatilis 6 TUR and $B$. plicatilis $\operatorname{IOM}\left(F_{1,10}=1.43\right.$, $\mathrm{p}=\mathrm{ns})$; the relative expression of $\mathrm{Na}^{+} / \mathrm{K}^{+}$ATPase for these sibling species increased 3.0-fold between 10 and $50 \%$. The relative expression of fragment B in B. plicatilis 6TUR and B. plicatilis IOM showed no consistent trend with salinity (data not shown).

\section{DISCUSSION}

The application of phylogenetic markers has proven useful in assessing the distributions and dispersal of free-living microbes. However, analysis of molecular data has raised some puzzling questions and in some cases paradoxes (e.g. De Meester et al. 2002). It is becoming clear that combinations of approaches, using phylogenetic and ecophysiological data to assess dispersal, gene flow, and habitat selection, are necessary to understand the processes governing the distributions of microbes (e.g. Ferris \& Palenik 1998, Moore et al. 1998, Papke et al. 2003). However, determining which functional or ecophysiological responses are ecologically most important for a particular organism, and analysing the components of those responses, is clearly a difficult task; thus, interdisciplinary approaches require careful assessment.

To illustrate and assess this approach we have examined differences between 3 sibling species in the Brachionus plicatilis species complex in an important osmoregulatory mechanism $\left(\mathrm{Na}^{+} / \mathrm{K}^{+}\right.$ATPase) likely to influence salinity tolerance. Our previous work has established differences in growth rate responses to salinity of these sibling species (Fig. 2c). Here, we extend these findings by determining if differences in $\mathrm{Na}^{+} / \mathrm{K}^{+}$ATPase activity reflected differences in salinity tolerances. We then assess whether molecular markers targeted at this mechanism could be used to rapidly measure salinity responses in $B$. plicatilis sibling species. Finally, we address the wider application of functional molecular markers for assessing the distributions and diversity of free-living microorganisms.

\section{Differences in $\mathrm{Na}^{+} / \mathrm{K}^{+}$ATPase between sibling species of Brachionus plicatilis}

We have previously indicated that Brachionus plicatilis 6TUR is an osmoregulator, based on the activity of $\mathrm{Na}^{+} / \mathrm{K}^{+}$ATPase in response to salinity. Here, we indicate similar enzymatic responses in additional isolates from the $B$. plicatilis species complex. $\mathrm{Na}^{+} / \mathrm{K}^{+}$ ATPase, in all cases, increased in response to salinities between 5 and $50 \%$ but then decreased at $60 \%$. We 


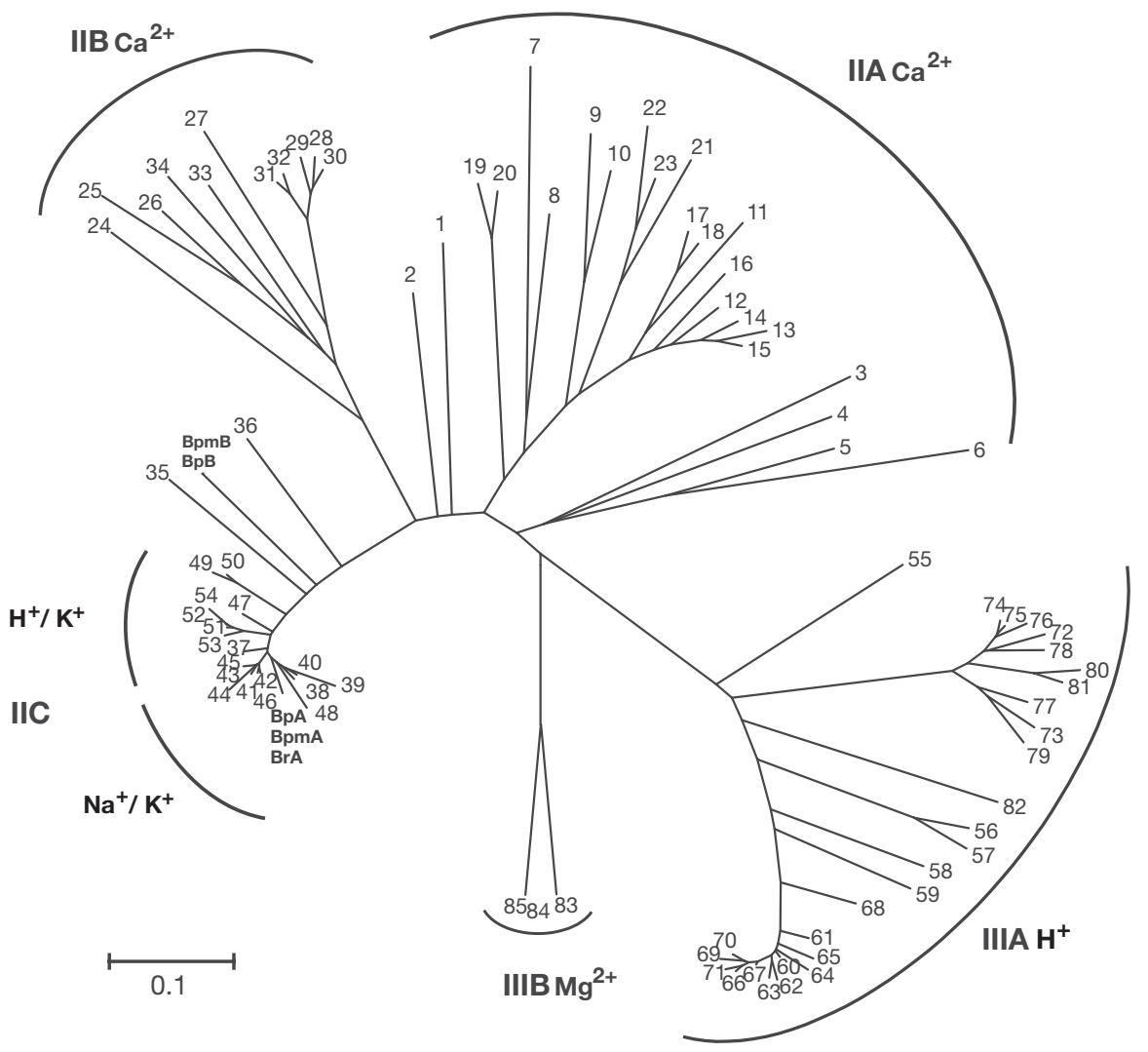

Fig. 3. Neighbor-joining phylogenetic tree based on core sequences of 91 P-type ATPases from subfamilies IIA-C and IIIA (following Axelsen \& Palmgren 1998). Ion specificity (inferred from GenBank sequence annotation) is given next to each subfamily. The positions of cDNA fragments A (putatively $\mathrm{Na}^{+} / \mathrm{K}^{+}$ATPase) and $\mathrm{B}$ from Brachionus plicatilis 6TUR (Bp), B. plicatilis IOM (Bpm), and $B$. rotundiformis 6TOS $(\mathrm{Br})$ are indicated in bold. GenBank accession numbers are as follows: $B$. plicatilis 6TUR fragment A (DQ116016), fragment B (DQ116019); B. plicatilis IOM fragment A (DQ116020), fragment B (DQ116020); B. rotundiformis fragment A (DQ116017)

have previously speculated on this pattern; potentially, decreases in activity signify the breakdown of the osmoregulatory response, or other osmotic stress mechanisms become active at higher salinities (Lowe et al. 2005a). Regardless of this, the activity of this mechanism appears highly conserved between sibling species.

While the trends in $\mathrm{Na}^{+} / \mathrm{K}^{+}$ATPase activity were similar, the magnitude of responses differed. Enzyme activity was higher in Brachionus rotundiformis 6TOS than in either B. plicatilis 6TUR or B. plicatilis IOM, which displayed indistinguishable responses. The differences in enzyme activity between sibling species appear to be the result of differences in gene expression. Relative expression of the $\mathrm{Na}^{+} / \mathrm{K}^{+}$ATPase transcript was again highest in $B$. rotundiformis 6 TOS, and did not differ between B. plicatilis 6TUR and B. plicatilis IOM. Thus, gene expression patterns paralleled enzyme activity responses.

The enzymatic and gene expression responses of $\mathrm{Na}^{+} / \mathrm{K}^{+}$ATPase seem to reflect differences in ecophysiolgical responses of sibling species to salinity. We have previously assessed growth rate responses to salinity of the sibling species examined in this study (modelled growth rate responses from C. D. Lowe et al. unpubl. are given in Fig. 2c); salinity tolerances were broad in all cases, but significant differences in responses occurred among all 3 siblings (C. D. Lowe et al. unpubl.). Brachionus rotundiformis 6TOS achieved the highest population growth rates in response to salinity (Fig. 2c) and displayed the highest activity of $\mathrm{Na}^{+} / \mathrm{K}^{+}$ATPase. However, for B. plicatilis 6TUR and $B$. plicatilis IOM, growth rate responses to salinity differed but enzyme and gene expression responses did not. In this case, the growth rate responses of these 2 sibling species were relatively similar and potentially the differences in gene expression and enzyme activity were too small for us to detect. Nevertheless, these data raise several useful points. First, $\mathrm{Na}^{+} / \mathrm{K}^{+}$ATPase is a potentially useful marker for salinity tolerance in $B$. plicatilis sibling species. Second, though we cannot necessarily infer 'cause and effect', the results indicate that a larger energetic investment in osmoregulation may allow higher population growth rates. Finally, differences between siblings in their ecophysiological responses and in the activity of underlying mechanisms exist, but may be subtle.

Although salinity is an important driving force that influences the distribution of sibling species (Derry et al. 2003a), data from this study (e.g. Fig. 2) do not support the large differences in physical niche parameters initially proposed to account for the differential distrib- 
ution of siblings (Gomez et al. 1995). Recent studies may shed light on this: sibling species distributions substantially overlap, and competition between siblings may influence distributions (e.g. Gomez et al. 1997, Ciros-Perez et al. 2001, Ortells et al. 2003). As a result, small differences in adaptive traits (e.g. osmoregulation and salinity tolerance) have potentially important impacts on distribution by altering interactions between sibling species (C. D. Lowe et al. unpubl.). Thus, studies such as this one are likely to be important to precisely characterise the subtle differences between sibling species in salient ecophysiological responses and their constituent mechanisms.

\section{$\mathrm{Na}^{+} / \mathrm{K}^{+}$ATPase as a functional marker for salinity tolerance in Brachionus plicatilis sibling species}

$\mathrm{Na}^{+} / \mathrm{K}^{+}$ATPase is a potentially useful indicator for salinity tolerance in Brachionus plicatilis sibling species: gene expression and enzyme activity both reflected ecophysiological responses to salinity. Establishing such responses is clearly an important step in the characterisation of functional variation. However, such assays are not easy to apply on large scales as they are time consuming and expensive. In an ecological context, one of the most useful applications of functional approaches is to assess the distributions of specific adaptations in populations in natural environments, without the need for continuous culturing and intensive experimentation. DNA-based molecular markers are clearly highly suited to such studies, as they can be easily assayed from preserved environmental samples using PCR-based approaches, but equally clearly, these markers require careful selection and assessment.

For the Brachionus plicatilis sibling species examined here, sequence variation in $\mathrm{Na}^{+} / \mathrm{K}^{+}$ATPase transcripts did not reflect differences between siblings in gene expression and enzyme activity. Transcripts were identical in $B$. plicatilis 6 TUR and $B$. rotundiformis 6TOS, but these siblings displayed different enzyme activity responses. Equally, transcripts in B. plicatilis 6TUR and $B$. plicatilis IOM differed by $\sim 4.0 \%$, but $\mathrm{Na}^{+} / \mathrm{K}^{+}$ATPase activity was similar. These comparisons raise an extremely important point: sequence variation does not necessarily reflect functional differences, and as a result variation should be interpreted cautiously.

In this particular case it is perhaps not surprising that sequence differences did not match functional variation. We have sequenced only $50 \%$ of the $\mathrm{Na}^{+} / \mathrm{K}^{+}$ ATPase $\alpha$-subunit (1517 bp of $\sim 3.0 \mathrm{~Kb}$ ) mRNA. The majority of the nucleotide substitutions we detected were synonymous (i.e. did not vary the amino acid sequences of the enzyme for which they code), and the small number of nonsynonymous changes would result in amino acid replacements in structural, rather than functional, regions of the enzyme. Thus, we would not expect such differences to influence enzyme activity or gene expression.

To an extent, we have illustrated one of the major problems associated with characterising functional mechanisms: identifying the salient features of adaptive traits is difficult. Nevertheless, the approach is undoubtedly a useful one to pursue. We have yet to develop easily applicable markers for salinity tolerance in Brachionus plicatilis. However, results from this study give a strong indication of where the critical genetic differences may occur. Differences between sibling species in $\mathrm{Na}^{+} / \mathrm{K}^{+}$ATPase activity occur as a result of differential expression of highly similar gene transcripts, which suggests differences in the gene regulatory mechanisms. While regulatory and signalling mechanisms are potentially complex, characterising them is not intractable. For example, the regulation of carbonic anhydrase, an important enzyme for the sequestration of $\mathrm{CO}_{2}$ at high salinities, in Dunaliella salina has been characterised (Fisher et al. 1996). Such approaches are likely to become increasingly accessible with the current rapid advances in genomic technologies.

\section{Is the integration of phylogenetic and functional molecular markers useful for assessing the distributions of microbes?}

Phylogenetic markers are now an integral component for the study of free-living microbial distributions. Their application has proven useful in assessing the spatial structures of microbial populations in natural environments and has revealed varying degrees of genetic variation across species distributions (LaJeunesse 2001, Whitaker et al. 2003). This application of molecular markers is, however, limited. At the centre of microbial biogeography there is a debate over the relative importance of processes such as dispersal and local habitat selection (Fenchel 2003). While phylogenetic markers provide an indication of population structures, only in some cases can they be used to infer the processes governing distributions. Thus, additional approaches are required.

Supporting one end of the debate, there is certainly genetic evidence for high dispersal rates and ubiquity (e.g. LaJeunesse 2001). However, there is also evidence of endemism (e.g. Whitaker et al. 2003), which may be a result of geographic isolation (i.e. limited dispersal) local habitat selection, or a combination of both processes. In several cases where endemism seems to 
occur, the relative impacts of adaptation and dispersal on species distributions have been assessed using combinations of phylogenetic and ecophysiological data. For instance, in oceanic Prochlorococcus, habitat selection and local adaptation structure populations, despite high dispersal; in contrast, in geothermal spring cyanobacteria, geographic isolation, not habitat selection, results in genetic differentiation (see 'Introduction'). However, there are less clear cases. In the marine coastal flagellate Oxyrrhis marina, salinity tolerances of geographic isolates correlate with habitat type, but not with rDNA genotype or spatial distribution (Lowe et al. 2005b). In this case, it is likely that some degree of dispersal between habitats occurs, and a less obvious combination of processes determines distributions and genetic structure.

This last example raises a critical issue: there is no inherent reason why patterns of diversity revealed by phylogenetic markers should correlate with adaptive traits (McKay \& Latta 2002). Certainly for sexually outbreeding eukaryotes, the phylogenies of specific DNA loci (potential molecular markers) can vary considerably, as genomes undergo segregation during mitosis (Avise 1994). Consequently, individuals or populations, which group based on one gene phylogeny, may group differently based on another gene phylogeny (Finlay 2004). This is a key reason why multiple molecular markers should be used to assess phylogenies (e.g. Gomez et al. 2002) and why, for example, rDNA diversity should not be used to infer adaptive differences (Knowlton 2000).

As illustrated above, there are situations where phylogenetic markers and adaptive traits are strongly correlated. This may occur where reproductive isolation, as a result of e.g. geographic separation and/or strong habitat selection, drives genealogical concordance across loci (Avise 1994, Knowlton 2000). Conversely, where barriers to dispersal or habitat selection pressures are less strong (as is likely the case for Oxyrrhis marina), dispersal and hybridisation between populations may allow the movement of neutral alleles but maintain differences in genes associated with adaptive traits (McKay \& Latta 2002). Given high dispersal potentials, the latter case is likely to be common for free-living eukaryotic microorganisms. In this context, combinations of phylogenetic and functional molecular markers are potentially powerful tools for quantifying the distribution of adaptive traits in populations and to assess the processes defining species distribution.

The combination of many approaches/techniques (e.g. molecular markers and ecophysiological responses) is likely to be useful for determining the processes that shape the biogeographies of microorganisms, though there are important challenges for their broad application. First, identifying the relevant genetic components of adaptive traits will be demanding and require considerable effort, although this is likely to become easier as genomic databases expand to include more free-living microorganisms. Second, these approaches will require quantitative measures of correlations between phylogenetic markers and genes associated with adaptive traits. Both theoretical and empirical approaches are being developed (e.g. McKay \& Latta 2002), though they are themselves contentious (e.g. Crnokrak \& Merilä 2002, Hendry 2002) and will undoubtedly require modifications to account for the varying reproductive strategies of many freeliving microorganisms.

Acknowledgements. This study forms part of a $\mathrm{PhD}$ thesis by C.D.L. at the University of Liverpool, funded by the Natural Environment Research Council (Grant No. NER/S/A/2001/ 0630). Thanks to Drs. A. Bates and D. Parry, who provided advice, equipment, and reagents for enzyme assays. P. Ferrer, S. Swift, and J. Watson provided valuable assistance with laboratory work. Drs. H. Noyes, I. Saccheri, and P. Watts provided valuable discussion.

\section{LITERATURE CITED}

Altschul SF, Madden TL, Schaffer AA, Zhang J, Zhang Z, Miller W, Lipman DJ (1997) Gapped BLAST and PSIBLAST: a new generation of protein database search programs. Nucleic Acids Res 25:3389-3402

Avise JC (1994) Molecular markers, natural history and evolution. Chapman \& Hall, London

Axelsen KB, Palmgren MG (1998) Evolution of substrate specificities in the P-type ATPase superfamily. J Mol Evol 46:84-101

Baas Becking LGM (1934) Geobiologie of inleidung tot de milieukunde. WP van Stockum \& Zoon, Den Haag

Bradford MM (1976) A rapid and sensitive method for the quantification of microgram quantities of protein utilizing the principle of protein-dye binding. Anal Biochem 151:369-374

Ciros-Perez J, Carmona MJ, Serra M (2001) Resource competition between sympatric sibling rotifer species. Limnol Oceanogr 46:1511-1523

Crnokrak P, Merilä J (2002) Genetic population divergence: markers and traits. Trends Ecol Evol 17:501

De Meester L, Gomez A, Okamura B, Schwenk K (2002) The Monopolization Hypothesis and the dispersal-gene flow paradox in aquatic organisms. Acta Oecol 23:121-135

Derry AM, Hebert PDN, Prepas EE (2003a) Evolution of rotifers in saline and subsaline lakes: a molecular phylogenetic approach. Limnol Oceanogr 48:675-685

Derry AM, Prepas EE, Hebert PDN (2003b) A comparison of zooplankton communities in saline lake water with variable anion composition. Hydrobiologia 505:199-215

Fenchel T (2003) Biogeography for bacteria. Science 301:925-926

Fenchel T, Finlay BJ (2004) The ubiquity of small species: patterns of local and global diversity. BioScience 54:777-784

Fenchel T, Esteban GF, Finlay BJ (1997) Local versus global diversity of microorganisms: cryptic diversity of ciliated protozoa. Oikos 80:220-225

Ferris MJ, Palenik B (1998) Niche adaptation in ocean cyanobacteria. Nature 396:226-228 
Finlay BJ (2004) Protist taxonomy: an ecological perspective. Phil Trans R Soc Lond 359:599-610

Fisher M, Gokhman I, Pick U, Zamir A (1996) A salt-resistant plasma membrane carbonic anhydrase is induced by salt in Dunaliella salina. J Biol Chem 271:17718-17723

Gomez A, Temprano M, Serra M (1995) Ecological genetics of a cyclical parthenogen in temporary habitats. J Evol Biol 8:601-622

Gomez A, Carmona MJ, Serra M (1997) Ecological factors affecting gene flow in the Brachionus plicatilis complex (Rotifera). Oecologia 111:350-356

Gomez A, Carvalho GR, Lunt DH (2000) Phylogeography and regional endemism of a passively dispersing zooplankter: mitochondrial DNA variation in rotifer resting egg banks. Phil Trans R Soc Lond B 267:2189-2197

Gomez A, Serra M, Carvalho GR, Lunt DH (2002) Speciation in ancient cryptic species complexes: evidence from the molecular phylogeny of Brachionus plicatilis (Rotifera). Evolution 56:1431-1444

Hendry AP (2002) Genetic population divergence: markers and traits. Trends Ecol Evol 17:502

Holliday CW (1990) Salinity-induced changes in branchial $\mathrm{Na}^{+} / \mathrm{K}^{+}$ATPase activity and transepithelial potential difference in the brine shrimp Artemia salina. J Exp Biol 151:279-296

Knowlton N (2000) Molecular genetic analysis of species boundaries in the sea. Hydrobiologia 420:73-90

LaJeunesse TC (2001) Investigating the biodiversity, ecology, and phylogeny of endosymbiotic dinoflagellates in the genus Symbiodinium using the ITS region: in search of a species level marker. J Phycol 37:866-880

Lingrel JB, Kuntzweiler T (1994) $\mathrm{NA}^{+}, \mathrm{K}^{+}$-ATPase. J Biol Chem 269:19659-19662

Lowe CD, Bates AD, Kemp SJ, Montagnes DJS (2005a) Evidence that the rotifer Brachionus plicatilis is not an osmoconformer. Mar Biol 146:923-929

Lowe CD, Day A, Kemp SJ, Montagnes DJS (2005b) There are high levels of functional and genetic diversity in Oxyrrhis marina. J Eukaryot Microbiol 52:250-257

Lubzens E, Zmora O, Barr Y (2001) Biotechnology and aquaculture of rotifers. Hydrobiologia 446/447:337-353

Lucu C, Devescovi M (1999) Osmoregulation and Branchial $\mathrm{Na}^{+}, \mathrm{K}^{+}$-ATPase in the lobster Hommerus gammarus acclimated to dilute seawater. J Exp Mar Biol Ecol 234:291-304

McKay JK, Latta RG (2002) Adaptive population divergence: markers, QTL and traits. Trends Ecol Evol 17:285-291

Editorial responsibility: John Dolan,

Villefranche-sur-Mer, France
Miracle MR, Serra M (1989) Salinity and temperature influence in rotifer life history characteristics. Hydrobiologia 186/187:81-102

Moon-van der Staay SY, De Wachter R, Vaulot D (2001) Oceanic 18S rDNA sequences from picoplankton reveals unexpected eukaryotic diversity. Nature 409:607-610

Moore LR, Rocap G, Chisholm SW (1998) Physiology and molecular phylogeny of coexisting Prochlorococcus ecotypes. Nature 393:464-467

Ortells R, Gomez A, Serra M (2003) Coexistence of cryptic rotifer species: ecological and genetic characterisation of Brachionus plicatilis. Freshw Biol 48:2194-2202

Palys T, Nakamura LK, Cohan FM (1997) Discovery and classification of ecological diversity in the bacterial world: the role of DNA sequence data. Int $\mathrm{J}$ Syst Bacteriol 47:1145-1156

Papke RT, Ramsing NB, Bateson MM, Ward DM (2003) Geographical isolation in hot spring cyanobacteria. Environ Microbiol 5:650-659

Pfaffl MW (2001) A new mathematical model for relative quantification in real-time PCR. Nucleic Acids Res 29:2002-2007

Rose TM, Schultz ER, Henikoff JG, Pietrokovski S, McCallum C, Henikoff S (1998) Consensus-degenerate hybrid oligonucleotide primers for amplification of distantly related sequences. Nucleic Acids Res 26:1628-1635

Rowan R (1998) Diversity and ecology of zooxanthallae on coral reefs. J Phycol 43:407-417

Saldarriaga JF, McEwan ML, Fast NM, Taylor FJR, Keeling PJ (2003) Multiple protein phylogenies show that Oxyrrhis marina and Perkinsus marinus are early branches of the dinoflagellate lineage. Int $\mathrm{J}$ Syst Evol Microbiol 53:355-365

Sambrook J, Russell DW (2001) Molecular cloning: a laboratory manual. Cold Spring Harbor Laboratory Press, New York

Walker KF (1981) A synopsis of ecological information on the saline lake rotifer Brachionus plicatilis Muller 1786. Hydrobiologia 81:159-167

Whitaker RJ, Grogan DW, Taylor JW (2003) Geographic barriers isolate endemic populations of hyperthermophilic Archaea. Science 301:976-978

Wilkinson DM (2003) Dispersal, cladistics and the nature of biogeography. J Biogeogr 30:1779-1780

Zar JH (1999) Biostatistical analysis. Prentice Hall International, London

Submitted: July 25, 2005; Accepted: September 8, 2005

Proofs received from author(s): October 19, 2005 